\title{
Transformation and fate of microphytobenthos carbon in subtropical, intertidal sediments: potential for long-term carbon retention revealed by ${ }^{13} \mathrm{C}$-labeling
}

\author{
J. M. Oakes and B. D. Eyre \\ Centre for Coastal Biogeochemistry, Southern Cross University, Lismore, Australia \\ Correspondence to: J. M. Oakes (joanne.oakes@scu.edu.au) \\ Received: 15 November 2013 - Published in Biogeosciences Discuss.: 16 December 2013 \\ Revised: 19 February 2014 - Accepted: 20 February 2014 - Published: 8 April 2014
}

\begin{abstract}
Microphytobenthos (MPB) are ubiquitous in coastal sediments, but the fate of their production (carbon biomass) is poorly defined. The processing and fate of MPBderived carbon in subtropical intertidal sediments was investigated through in situ labeling with ${ }^{13} \mathrm{C}$-bicarbonate. Of the added ${ }^{13} \mathrm{C}, 100 \%$ was fixed within $\sim 4 \mathrm{~h}$, suggesting that MPB productivity was limited by inorganic carbon availability. Although there was rapid transfer of ${ }^{13} \mathrm{C}$ to bacteria (within $12 \mathrm{~h}$ ), a relatively small fraction of ${ }^{13} \mathrm{C}$ was transferred to heterotrophs (up to $12.5 \%$ of total fixed ${ }^{13} \mathrm{C}$ into bacteria and $0.01 \%$ into foraminifera). MPB was the major reservoir for ${ }^{13} \mathrm{C}$ throughout the study, suggesting that production of extracellular polymeric substances was limited and/or MPB recycled ${ }^{13} \mathrm{C}$. This retention of ${ }^{13} \mathrm{C}$ was reflected in remarkably slow estimated turnover times for the MPB community (66-100d). Over $31 \mathrm{~d}, \sim 70 \%$ of the ${ }^{13} \mathrm{C}$ was lost from sediments. This was primarily via resuspension $(\sim 55 \%)$, enhanced by elevated freshwater flow following rainfall. A further $\sim 13 \%$ was lost via fluxes of dissolved inorganic carbon during inundation. However, ${ }^{13} \mathrm{C}$ losses via dissolved organic carbon fluxes from inundated sediments $(0.5 \%)$ and carbon dioxide fluxes from exposed sediments $(<0.1 \%)$ were minimal. The retention of $\sim 30 \%$ of the carbon fixed by MPB within one tidal exposure after $>30 \mathrm{~d}$, despite high resuspension, demonstrates the potentially substantial longer term retention of MPB-derived carbon in unvegetated sediments and suggests that MPB may contribute to carbon burial ("blue carbon").
\end{abstract}

\section{Introduction}

Sediments at the land-ocean interface are sites of rapid organic matter transformation. Due to the high availability of light and nutrients (Heip et al. 1995), benthic communities in coastal sediments are often dominated by microscopic photoautotrophs (microphytobenthos, or MPB). MPB are highly productive and fix inorganic carbon from overlying water or air (in intertidal sediments). This carbon may undergo various transformations before being ultimately lost to the overlying water column or buried within sediments. As well as being directly consumed, MPB can exude much of their production (up to $73 \%$; Goto et al., 2001) as extracellular polysaccharides (EPS), particularly where there is low nutrient availability (Cook et al., 2007). MPB and their EPS provide a labile carbon source for bacteria (Bellinger et al., 2009; Oakes et al., 2010b) and higher order consumers (Middelburg et al., 2000; Oakes et al., 2010a). Ultimately, MPB, EPS, and organic matter containing MPB-derived carbon may be lost via resuspension (de Jonge and van Beusekom, 1995; Hanlon et al., 2006) or removed by mobile consumers. Alternatively, processing within sediments can result in loss of MPB-derived carbon via fluxes of dissolved organic carbon (DOC), dissolved inorganic carbon (DIC) or carbon dioxide $\left(\mathrm{CO}_{2}\right.$; exposed sediments). DOC fluxes can include EPS (Smith and Underwood, 2000), but DOC can also be released from algae via cell lysis by viruses, bacteria, or grazers (Agustí and Duarte, 2013). Remineralization of organic matter containing MPB-derived carbon results in fluxes of inorganic carbon $\left(\mathrm{CO}_{2}, \mathrm{HCO}_{3}^{-}, \mathrm{CO}_{3}^{2-}\right)$ that contribute to losses of fixed carbon. All these inorganic carbon forms can diffuse to overlying water as DIC while sediment is 
inundated, but only $\mathrm{CO}_{2}$ is released from sediment exposed to air. These various transformation pathways for the carbon fixed by MPB affect the quality and quantity of carbon inputs to the coastal ocean.

Despite the potential importance of MPB processing pathways in coastal sediments, these have not been well defined. Stable isotope labeling is a powerful approach for tracing carbon in coastal systems, and has been used in a number of studies to trace assimilation of MPB-derived carbon by bacteria and higher consumers (e.g. Middelburg et al., 2000; Oakes et al., 2010b; Evrard et al., 2012). More recently carbon stable isotope labeling has also been used to trace pathways of loss for MPB-derived carbon, including fluxes of DIC (Evrard et al., 2010, Oakes et al., 2011; Oakes et al., 2012) and DOC (Oakes et al., 2011; Oakes et al., 2012), and loss of $\mathrm{CO}_{2}$ due to respiration of algal carbon (phytodetritus) in intertidal sediments (Maher et al., 2013; Oakes et al., 2013). Carbon stable isotope labeling has been used in a few studies in intertidal muds and sands and shallow subtidal sands in temperate regions to investigate the processing of MPB-derived carbon, but there has been only one study in the subtropics, which looked at shallow subtidal sands (Oakes et al., 2012). No studies have investigated the transformation and fate of MPB-derived carbon in subtropical intertidal sediments.

The processing of MPB-derived carbon in subtropical sediments may be fundamentally different to processing in temperate sediments. Differences in tidal movement may affect rates of sediment resuspension and flushing, and temperature differences may affect the rate and relative importance of carbon transformation pathways (Middelburg et al., 1996). In addition, the higher biomass and productivity of bacteria that is typical of sediments in warmer climates (Alongi, 1994) may also affect the rate and pathways of carbon processing. The only study to have assessed the processing of MPB-derived carbon in subtropical sediment (shallow subtidal sands; Oakes et al., 2012) reported marked differences in the fate of carbon (greater burial and retention) compared to previous studies of sands and muds in the intertidal zone within temperate areas (e.g. Middelburg et al., 2000; Bellinger et al., 2009). However, it was not clear whether these differences reflected variations in climate and associated microbial communities, subtidal versus intertidal differences, the size of the systems studied and their connection with the ocean, or some other factor.

An impediment to understanding MPB carbon processing across all systems is the relatively short timescale over which studies have been done (e.g. 4-6d; Middelburg et al., 2000; Evrard et al., 2008, 2010). We recently showed that $30 \%$ of the carbon fixed by MPB within $1 \mathrm{~d}$ remained in subtropical shallow subtidal sands after 30 days (Oakes et al., 2012). There has recently been considerable focus on the carbon sink potential of coastal habitats ("Blue carbon"), but the focus has been on vegetated habitats (Duarte et al., 2005; McLeod et al., 2011; Duarte et al., 2013). Al- though MPB lack the extensive below-ground biomass of other habitats, the long-term retention of carbon fixed by MPB in unvegetated subtropical sands observed previously suggests that MPB-derived carbon may accumulate within sediments, thereby contributing to carbon sequestration.

In this study we aimed to combine in situ stable isotope labeling with measurements of DOC, DIC, and $\mathrm{CO}_{2}$ fluxes and assimilation in sediment compartments to quantify the pathways for transformation and ultimate fate, including burial, of MPB-derived carbon in subtropical intertidal sediments over the longer term (31 d). Few studies have looked at processing of MPB carbon in situ (Middelburg et al., 2000; Bellinger et al., 2009; Oakes et al., 2010b; Oakes et al., 2012), and only the latter two of these have considered such an extended time period. We expected that the carbon fixed by MPB in subtropical intertidal sediments would be more susceptible to removal by resuspension compared to that in subtropical subtidal sediments. We further expected that subtropical intertidal sediments would have greater potential for retaining MPB-derived carbon than temperate intertidal sediments, due to greater processing and recycling by the more active microbial community.

\section{Methods}

\subsection{Site description}

The study site was an intertidal shoal in the lower Richmond River estuary, subtropical New South Wales, Australia $\left(28^{\circ} 52^{\prime} 25.01^{\prime \prime} \mathrm{S}, 153^{\circ} 33^{\prime} 20.43^{\prime \prime} \mathrm{E}\right)$. The river has a catchment of $\sim 6900 \mathrm{~km}$ with annual rainfall of $\sim 1300 \mathrm{~mm}$ (McKee and Eyre, 2000) and an average flow rate of $\sim 2200$ $\mathrm{ML} \mathrm{d}^{-1}$ (daily gauged flow adjusted for catchment area, averaged over years for which data was available; 1970-2013). The catchment is subject to frequent episodic rainfall events, and associated flooding, resulting in highly variable estuary flushing, salinity, and nutrient concentrations (Eyre and Twigg, 1997; Eyre, 2000). For details of the hydrology and biogeochemistry of the Richmond River, refer to McKee and Eyre (2000) and Eyre and Twigg (1997).

Sediment at the site was sandy mud, with the surface layer $(0-2 \mathrm{~cm}$ depth) dominated by fine sand $(125-250 \mu \mathrm{m}$; $68 \%)$ and very fine sand $(63-125 \mu \mathrm{m} ; 23 \%)$. Deeper sediments $(2-10 \mathrm{~cm})$ were also dominated by fine sand $(\sim 78 \%)$, but had a lower contribution of very fine sand $(\sim 12 \%)$ and a greater contribution of medium sand $(\sim 10 \%)$. Based on $\mathrm{O}_{2}$ fluxes in control cores, the site was net autotrophic (ratio of production to respiration $(p / r)=2.23$ ). Examination by light microscopy $(100 \times)$ showed that the microphytobenthos was dominated by diatoms. No cyanobacteria were observed. Gross productivity (GPP) of inundated sediments based on $\mathrm{O}_{2}$ fluxes in control cores was $4.5 \pm 1.5 \mathrm{mmol} \mathrm{C} \mathrm{m}^{-2} \mathrm{~h}^{-1}$ (assuming $\mathrm{O}_{2}: \mathrm{C}=1: 1$ ). Surface sediments $(0-2 \mathrm{~cm})$ had an organic carbon (OC) content of 
$146.8 \pm 18.7 \mathrm{~g} \mathrm{~m}^{-2}$. Sediment organic matter at depths of 0 $2 \mathrm{~cm}, 2-5 \mathrm{~cm}$ and $5-10 \mathrm{~cm}$ had molar $\mathrm{C}: \mathrm{N}$ ratios of 15.8 , 14.1 and 11.1 , respectively.

\section{$2.2{ }^{13}$ C-labeling}

At the beginning of low tide two experimental plots $(1 \mathrm{~m} \times 1 \mathrm{~m})$ were established within $10 \mathrm{~m}$ of one another on the intertidal shoal by pushing aluminium frames $3 \mathrm{~cm}$ into the sediment such that their upper surface was flush with the sediment. String stretched across each frame divided the plots into grids of $20 \mathrm{~cm} \times 20 \mathrm{~cm}$ squares. An equal quantity of ${ }^{13} \mathrm{C}$-labeled $\mathrm{NaHCO}_{3}\left(99 \%{ }^{13} \mathrm{C}\right)$ dissolved in filtered $(\mathrm{GF} / \mathrm{F})$ site water was applied to the sediment surface within each square using a motorized sprayer. This ensured even application of ${ }^{13} \mathrm{C}$ across each plot, equivalent to $11.5 \mathrm{mmol}^{13} \mathrm{C} \mathrm{m}^{-2}$. The ${ }^{13} \mathrm{C}$-labeled plots remained exposed to air for $\sim 4 \mathrm{~h}$ of daylight before tidal inundation. One tidal inundation was allowed to occur before the first sampling to remove any ${ }^{13} \mathrm{C}$-enriched sodium bicarbonate that had not been incorporated by MPB. Frames were left in place for the duration of the study.

\subsection{Sample collection}

During low tide when the sediments were exposed at 0.5 , $1,3,10,20$ and $30 \mathrm{~d}$ after ${ }^{13} \mathrm{C}$-labeling, one core of sediment $(9 \mathrm{~cm}$ diameter $\times \sim 20 \mathrm{~cm}$ depth) was collected from each plot using a Plexiglas ${ }^{\circledR}$ core liner for incubation in the laboratory. At 0.5, 10 and $30 \mathrm{~d}$ after ${ }^{13} \mathrm{C}$-labeling, two cores of sediment were also collected from 5-10 m outside of each plot for incubation to determine background (control) isotope values of sediment compartments (at depths of $0-2 \mathrm{~cm}, 2-$ $5 \mathrm{~cm}$, and $5-10 \mathrm{~cm}$ ) and fluxes. Incubation of cores delayed collection of sediment samples by at least $5 \mathrm{~h}$. Therefore, on the first two sampling occasions ( 0.5 and $1 \mathrm{~d}$ ), when the most rapid changes in ${ }^{13} \mathrm{C}$ distribution among sediment compartments were expected, an additional core was collected from within each plot to allow immediate collection of sediment for analysis. These cores were immediately split into sediment depth layers of $0-2 \mathrm{~cm}, 2-5 \mathrm{~cm}$, and $5-10 \mathrm{~cm}$, which were stored frozen prior to analysis of ${ }^{13} \mathrm{C}$ within sediment organic carbon (OC), fauna, MPB and bacteria. To minimize site disturbance, PVC pipes filled with site sediment $(90 \mathrm{~mm}$ diameter, $20 \mathrm{~cm}$ long) were placed in the holes left following core removal on each sampling occasion.

Because the site was intertidal, each core was incubated in the dark and the light with water overlying the sediment (inundated conditions), and in the dark and light with water drained from the core (exposed conditions). Cores were incubated for $\sim 5$ to $6 \mathrm{~h}$ under each set of conditions (dark inundated, light inundated, dark exposed, and light exposed). Incubations began immediately upon return to the laboratory, under conditions reflecting those in the field at the time (e.g. light exposed incubations occurred during day- light hours when there was a low tide at the study site). Control cores and ${ }^{13} \mathrm{C}$-labeled cores were incubated in separate chambers of water maintained at approximately in situ temperature $\left(18.5 \pm 1{ }^{\circ} \mathrm{C}\right)$ and light levels $(1200 \mu \mathrm{mol}$ photons $\left.\mathrm{m}^{-2} \mathrm{~s}^{-1} \pm 5 \%\right)$.

For exposed incubation, any water overlying the sediment was carefully siphoned off, taking care to avoid disturbing the sediment surface, and weighted containers and foam pads were used to raise the sediment within each core sleeve so that the sediment surface was within $\sim 1 \mathrm{~cm}$ of a gas-tight Plexiglas ${ }^{\circledR}$ lid containing two septa. Weighted containers were used to prevent the cores from floating within the incubation chambers, whilst the foam pads, which fitted tightly within the core sleeves, allowed for finer adjustment of sediment height whilst preventing drainage of interstitial porewater. At the start and end of each exposed incubation period $2 \mathrm{~mL}$ sample of the air overlying the sediment within each core was withdrawn into a gas-tight syringe through one of the septa in the core lid. However, samples for the first three sampling periods were lost. Sampled air was transferred to $12 \mathrm{~mL}$ Exetainers ${ }^{\circledR}$ prefilled with degassed water, which were held upside down as air was injected. Displaced water escaped via a second syringe tip placed through the septa in each exetainer lid.

For inundated incubations, cores were gently filled with site water, taking care not to disturb the sediment surface, and capped with gas-tight Plexiglas ${ }^{\circledR}$ lids containing sampling ports. When an inundated incubation followed an exposed incubation, the weighted containers and foam pads used to raise the sediment for exposed incubation were removed, and the core of sediment was allowed to gently slide back to the base of the core sleeve before water was added. Within each inundated core, an external rotating magnet operated magnetic stir bars suspended $\sim 5 \mathrm{~cm}$ above the sediment surface, maintaining water circulation below the sediment resuspension threshold. At the start and end of each incubation period, the dissolved oxygen concentration within each core was measured $\left( \pm 0.01 \mathrm{mg} \mathrm{L}^{-1}\right.$; Hach HQ40d, luminescent DO probe) and $\sim 50 \mathrm{~mL}$ of water was removed from each core. Sampled water was syringe filtered (precombusted GF/F) into precombusted $40 \mathrm{~mL}$ glass vials with Teflon ${ }^{\circledR}$

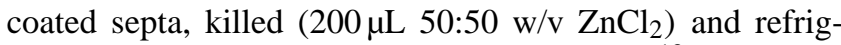
erated, without headspace, until analysis for $\delta^{13} \mathrm{C}$ and concentrations of dissolved organic carbon (DOC) and dissolved inorganic carbon (DIC). Additional water samples were collected for a separate study. Sampled water was replaced, as it was withdrawn, with site water from a collapsible reservoir.

At the conclusion of the incubation procedure, sediment was extruded and sectioned $(0-2 \mathrm{~cm}, 2-5 \mathrm{~cm}$, and $5-10 \mathrm{~cm}$ depths) for analysis of sediment OC, fauna, and phospholipid-derived fatty acid (PLFA) biomarkers for MPB and bacteria. 


\subsection{Sample analysis}

Natural abundance and enriched stable isotope samples were analyzed separately to prevent contamination.

The concentrations and $\delta^{13} \mathrm{C}$ of DOC and DIC were measured via continuous-flow wet-oxidation isotope-ratio mass spectrometry using an Aurora 1030W total organic carbon analyzer coupled with a Thermo Delta V Plus Isotope Ratio Mass Spectrometer (IRMS) as described by Oakes et al. (2011).

The $\delta^{13} \mathrm{C}$ of $\mathrm{CO}_{2}(\mathrm{~g})(0.1 \%$ o reproducibility) was determined using a preconcentration system attached to a Thermo Trace GC Ultra gas chromatograph with a Porapak Q column $(30 \mathrm{~m} \times 0.32 \mathrm{~mm})$ coupled to a Delta V Plus Isotope Ratio Mass Spectrometer (IRMS) via a Conflo III interface. The sample headspace was purged directly into the preconcentration system using helium flow and was concentrated at $-65^{\circ} \mathrm{C}$ using HaySep Q as a chemical sieve, and desorbed at $150^{\circ} \mathrm{C}$ onto the GC column. The GC oven was held at $40^{\circ} \mathrm{C}$, and the flow rate of the helium carrier gas was $3 \mathrm{~mL} \mathrm{~min}^{-1}$. Because variations in $\mathrm{CO}_{2}(\mathrm{~g})$ concentration were within the range of instrument error, a constant $\mathrm{CO}_{2}(\mathrm{~g})$ concentration was assumed (typical atmospheric concentration, $\left.15.6 \mu \mathrm{mol} \mathrm{L}^{-1}\right)$.

Macrofauna was only occasionally encountered at the site. This low abundance, combined with high mobility of the observed taxa, prevented assessment of their use of MPB carbon. Individuals would not have remained within the labeled area and containment would have drastically altered their behaviour. We therefore focused on small fauna retained on $63 \mu \mathrm{m}$ to $500 \mu \mathrm{m}$ sieves (meiobenthos). Due to the laborious nature of this work, only a single sample $(n=1)$ was analyzed for each of days 3,10 , and 30 , and only for surface sediments. Fauna were sorted under a dissecting microscope. Biomass was determined by manually removing (under a dissecting microscope) and weighing all meiobenthos, sorted by taxa, from a known quantity of homogenized sediment. For dominant taxa, based on biomass, individual organisms were manually removed from the sediment under a dissecting microscope to obtain sufficient material for isotope analysis.

Sediment and fauna samples were lyophilized, homogenized, weighed into silver cups, and acidified $(5 \% \mathrm{HCl})$ prior to the determination of $\delta^{13} \mathrm{C}( \pm 0.2 \%)$ and $\% \mathrm{C}$ (error $\sim 1.0 \%$ of measured value) using a Thermo Finnigan Flash Elemental Analyzer 112 interfaced via a Thermo Conflo III with a Thermo Delta V Plus Isotope Ratio Mass Spectrometer (EA-IRMS). The $\% \mathrm{~N}$ of unacidified subsamples of sediment was also determined via EA-IRMS, allowing calculation of molar $\mathrm{C}: \mathrm{N}$ ratios for sediment $\mathrm{OC}$. Helium dilution of the carrier stream was turned off for foraminifera samples to reduce the required mass.

Phospholipid biomarkers (PLFAs) to determine ${ }^{13} \mathrm{C}$ uptake into MPB and bacteria were extracted from lyophilized sediments following the addition of an internal standard (tridecanoic acid, $\mathrm{C}_{13}$ ), using a modified Bligh and Dyer method (Oakes et al., 2010b). PLFA concentrations and $\delta^{13} \mathrm{C}$ were determined using a Thermo Trace GC Ultra gas chromatograph coupled with a Thermo Delta V Plus IRMS via a Thermo Conflo III interface (Oakes et al., 2010b). The column used was a $60 \mathrm{~m}$ nonpolar HP5-MS (J\&W Scientific, $0.32 \mathrm{~mm}$ i.d., $0.25 \mu \mathrm{m}$ film thickness).

\subsection{Calculations}

PLFA $\delta^{13} \mathrm{C}$ values were corrected for the addition of a carbon atom during methylation as described by Jones et al. (2003). Natural abundance $\delta^{13} \mathrm{C}$ values for bacteria and MPB were calculated using $\delta^{13} \mathrm{C}$ values of PLFA markers for bacteria $(\mathrm{i}+\mathrm{a} 15: 0)$ and diatoms $(16: 1(\mathrm{n}-7))$ in control core sediments, corrected for fractionation of $-5.0 \%$ (middle of range identified by Boschker et al., 1999) and $-5.4 \%$ (Schouten et al., 1998), as described by Oakes et al. (2010b).

Total ${ }^{13} \mathrm{C}$ uptake into sediment $\mathrm{OC}$, fauna, bacteria, and MPB $\left(\mu \mathrm{mol}{ }^{13} \mathrm{C} \mathrm{m}^{-2}\right.$ ) was calculated as described by Oakes et al. (2012) based on the quantity of excess ${ }^{13} \mathrm{C}$ in each sample and the carbon biomass of each compartment. Carbon biomass of sediment and fauna was the product of $\% \mathrm{C}$ and total dry mass per unit area. For fauna, the total number of individuals per $\mathrm{m}^{2}$ was estimated based on the number of individuals within sediment subsamples of known volume. Total mass was determined by multiplying this estimate by the average mass of an individual, based on the mass of a known number of individuals.

The PLFAs selected as biomarkers were i15 : 0 and a15:0 for bacteria, and $16: 1(\mathrm{n}-7)$ and $20: 5(\mathrm{n}-3)$ for MPB. Although $16: 1(\mathrm{n}-7)$ is abundant in diatoms (Volkman et al., 1989) it can also occur in cyanobacteria (which were absent from the study site) and gram-negative bacteria. However, based on the ratio of $i 15: 0$ and a15:0 to $16: 1(n-7)$ in bacteria-dominated sediments (Rajendran et al., 1994), we estimated that bacteria contributed only $1.8 \pm 0.2 \%$ of the $16: 1(\mathrm{n}-7)$ in our sediments. We therefore considered $16: 1(n-7)$ to be a suitable biomarker for MPB in this study.

Concentrations of PLFA biomarkers for bacteria (i15: 0 and a15:0) and MPB (16:1(n-7) and 20:5(n-3)) were calculated based on their peak areas relative to the $\mathrm{C}_{13}$ internal standard. Total biomass of bacteria and MPB was calculated as described by Oakes et al. (2010b). The average fraction of MPB PLFAs represented by $16: 1(n-7)$ and $20: 5(n-3)$ was estimated to be 0.37 , based on the PLFA composition of diatoms (Volkman et al., 1989), which were the dominant MPB taxa at the study site. Similarly, the average fraction of bacterial PLFAs represented by $\mathrm{i}+\mathrm{a} 15: 0$ was estimated based on the PLFA composition of sediments dominated by bacteria (Rajendran et al., 1993; Rajendran et al., 1994). Biomass estimates for MPB and bacteria calculated using minimum and maximum fraction values $(32.5 \%$ and $41.1 \%$ for diatoms; $9.8 \%$ to $21.2 \%$ for bacteria) were within $13 \%$ and $60 \%$, respectively, of biomass estimates based on average fraction values. 
Transfer of ${ }^{13} \mathrm{C}$ into DOC and DIC in the water column and $\mathrm{CO}_{2}$ in air was calculated for the beginning and end of the dark incubation period and for the end of the light period as the product of excess ${ }^{13} \mathrm{C}$ in DOC, DIC, or $\mathrm{CO}_{2}$ (fraction ${ }^{13} \mathrm{C}$ in labeled sample - average fraction ${ }^{13} \mathrm{C}$ in equivalent control samples), water or air volume within the core, and the concentration of DOC or DIC, or assumed concentration of $\mathrm{CO}_{2}\left(15.6 \mu \mathrm{mol} \mathrm{L}{ }^{-1}\right)$. The total flux of excess ${ }^{13} \mathrm{C}$ in DOC, DIC, or $\mathrm{CO}_{2}$ during dark or light incubation was then calculated as follows:

Excess ${ }^{13} \mathrm{C}$ flux $=\left(\right.$ Excess ${ }^{13} \mathrm{C}_{\text {start }}-$ Excess $\left.{ }^{13} \mathrm{C}_{\text {end }}\right) /(\mathrm{SA} \times t)$

where excess ${ }^{13} \mathrm{C}_{\text {start }}$ and excess ${ }^{13} \mathrm{C}_{\text {end }}$ represent excess ${ }^{13} \mathrm{C}$ at the beginning and end of the dark or light incubation period, SA is the sediment surface area within a core, and $t$ represents hours of dark or light incubation. Net fluxes (excess ${ }^{13} \mathrm{C} \mathrm{m}^{-2} \mathrm{~d}^{-1}$ ) of DOC, DIC, or $\mathrm{CO}_{2}$ were calculated as follows:

Net flux $=($ dark flux $/$ dark hours $)+($ light flux $/$ light hours $) \times t$,

where $t$ represents the number of hours of sediment inundation (for DOC and DIC fluxes) or exposure ( $\mathrm{CO}_{2}$ fluxes). We interpolated between measured net flux values and estimated the total quantity of ${ }^{13} \mathrm{C}$ lost via fluxes of DOC, DIC, and $\mathrm{CO}_{2}$ from the end of labeling up until each sampling period by determining the area under the curve.

A 2-G model (Westrich and Berner 1984) determined the rate of ${ }^{13} \mathrm{C}$ loss from total sediment $\mathrm{OC}(0-10 \mathrm{~cm})$ from each experimental plot, as follows:

$$
G_{T}(t)=G_{1}\left[\exp \left(-k_{1} t\right)\right]+G_{2}\left[\exp \left(-k_{2} t\right)\right]+G_{\mathrm{NR}},
$$

where $G_{T}$ is represents ${ }^{13} \mathrm{C}$ incorporation into sediment $\mathrm{OC}$, $t$ is time, $G_{1}, G_{2}$, and $G_{N R}$ represent ${ }^{13} \mathrm{C}$ incorporation into highly reactive, less reactive, and non-reactive (over the timescale of the experiment) fractions of sediment OC, and $k_{1}$ and $k_{2}$ represent first-order decay constants for $G_{1}$ and $G_{2}$, respectively.

\section{Results}

\subsection{Estuary conditions}

Around $35 \mathrm{~d}$ before sampling began a rainfall event increased freshwater flow rates at the head of the estuary to a maximum of $24248 \mathrm{ML} \mathrm{d}^{-1}$. Although flow rates at the head of the estuary decreased to typical levels $\left(\sim 2000 \mathrm{ML} \mathrm{d}^{-1}\right)$ and remained so for the first three sampling occasions (up to $4 \mathrm{~d}$ after label application, Fig. 1), another rain event then increased flow to $39757 \mathrm{ML} \mathrm{d}^{-1}$ within $9 \mathrm{~d}$ of label application (Fig. 1). Flow rates remained elevated for the fourth sampling occasion ( $37952 \mathrm{ML} \mathrm{d}^{-1}$ ), but declined rapidly thereafter. However, flow remained elevated above typical levels

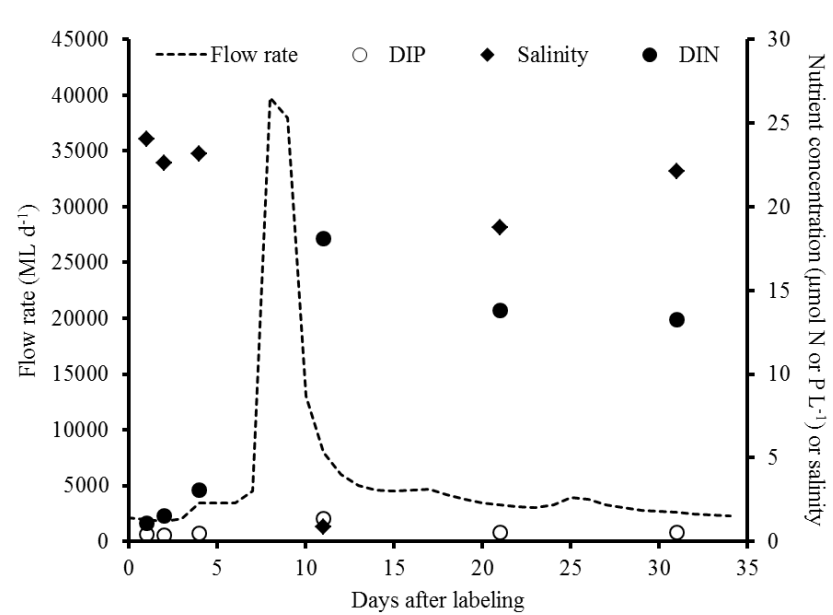

Fig. 1. Variations in flow rate of the Richmond River and variations in salinity, dissolved inorganic nitrogen concentration (DIN), and dissolved inorganic phosphorus concentration (DIP) at the study site during the study period.

for the remainder of the study period, with rates of $\sim 3000$ $4000 \mathrm{ML} \mathrm{d}^{-1}$ in the final days of the study. These variations in flow rate are typical of the estuary (Eyre \& Twigg, 1997; Eyre, 2000) and corresponded with variations in salinity ( 0.91 to 24.04 ) and concentrations of dissolved inorganic nitrogen $\left(1.02\right.$ to $\left.18.11 \mu \mathrm{mol} \mathrm{L}^{-1}\right)$ and dissolved inorganic phosphorus $(0.37$ to $1.36 \mu \mathrm{mol} \mathrm{L}-1)$ over the duration of the study (Fig. 1).

\subsection{Sediment organic carbon distribution}

Sediment OC content was higher by volume in shallower sediments (average over the study of $611 \pm 78 \mu \mathrm{mol} \mathrm{mL} \mathrm{m}^{-1}$ in $0-2 \mathrm{~cm}$ sediments) than in deeper sediments $\left(418 \pm 46 \mu \mathrm{mol} \mathrm{C} \mathrm{mL} L^{-1}\right.$ in $2-5 \mathrm{~cm}$ sediments, $333 \pm 23 \mu \mathrm{mol} \mathrm{mL} \mathrm{m}^{-1}$ in $5-10 \mathrm{~cm}$ sediments). The total OC content of surface sediments decreased by $\sim 24 \%$ over the duration of the study.

On average, MPB and bacteria together accounted for $\sim 89 \%$ of the OC in $0-2 \mathrm{~cm}$ sediments (Table 1 ) and $\sim 77 \%$ of the OC in $2-5 \mathrm{~cm}$ sediments. However, whereas MPB and bacteria had similar biomass in surface sediments, there was a marked decline in MPB biomass in deeper sediments, with MPB accounting for $\sim 24 \%$ of OC in $2-5 \mathrm{~cm}$ sediments, and only $\sim 3 \%$ of OC in deeper sediments. Bacteria represented $\sim 44 \%$ and $54 \%$ of the OC in $0-2 \mathrm{~cm}$ and $2-5 \mathrm{~cm}$ sediments, respectively, but accounted for only $11.6 \%$ of the OC in 5-10 cm sediments. MPB and bacteria in surface sediments showed similar declines in biomass over the duration of the study, with respective losses over $31 \mathrm{~d}$ of $\sim 35 \%$ and $\sim 40 \%$.

A total of 51 species of meiobenthos were recorded, and these were primarily foraminiferans. Only two species (Elphidium advenum and Ammonia beccarii) were common to 
Table 1. Mean natural abundance carbon stable isotope ratios $\left(\delta^{13} \mathrm{C}\right)$, biomass (standard errors in brackets), and $\%$ of sediment organic carbon (\% OC) represented by sediment compartments at depths of $0-2 \mathrm{~cm}, 2-5 \mathrm{~cm}$ and $5-10 \mathrm{~cm}$, based on control samples. Note that $\delta^{13} \mathrm{C}$ values for bacteria and MPB are for whole cells. Units are per area, not volume. $\delta^{13} \mathrm{C}$ of uncharacterized material estimated using isotope mixing models. Sample size for all means and standard errors $=6$.

\begin{tabular}{|c|c|c|c|c|c|c|c|c|c|}
\hline \multirow[b]{2}{*}{ Compartment } & \multicolumn{3}{|c|}{$0-2 \mathrm{~cm}$} & \multicolumn{3}{|c|}{$2-5 \mathrm{~cm}$} & \multicolumn{3}{|c|}{$5-10 \mathrm{~cm}$} \\
\hline & $\delta^{13} \mathrm{C}$ & $\begin{array}{c}\text { Biomass } \\
\left(\mathrm{mmol} \mathrm{C} \mathrm{m}^{-2}\right)\end{array}$ & $\%$ OC & $\delta^{13} \mathrm{C}$ & $\begin{array}{c}\text { Biomass } \\
\left(\mathrm{mmol} \mathrm{C} \mathrm{m}^{-2}\right)\end{array}$ & $\% \mathrm{OC}$ & $\delta^{13} \mathrm{C}$ & $\begin{array}{c}\text { Biomass } \\
\left(\mathrm{mmol} \mathrm{C} \mathrm{m}^{-2}\right)\end{array}$ & $\%$ OC \\
\hline Sediment OC & $-16.0(1.0)$ & $12221.8(1557.2)$ & 100 & $-16.3(0.3)$ & $12550.3(1369.3)$ & 100 & $-14.4(0.2)$ & $16637.8(1151.8)$ & 100 \\
\hline Microphytobenthos & $-14.3(0.6)$ & $5518.6(461.9)$ & $45.1(3.8)$ & $-13.0(0.3)$ & $2972.9(962.4)$ & $23.7(7.7)$ & $-14.4(0.5)$ & $481.9(82.1)$ & $2.9(0.5)$ \\
\hline Bacteria & $-15.6(0.7)$ & $5404.1(593.2)$ & $44.2(4.8)$ & $-15.0(0.7)$ & $6726.5(2526.3)$ & $53.6(20.1)$ & $-14.9(0.4)$ & $1929.6(865.8)$ & $11.6(5.2)$ \\
\hline Elphidium advenum & -16.4 & $2.1(0.9)$ & $0.01(0.01)$ & n.d. & n.d. & n.d. & n.d. & n.d. & n.d. \\
\hline Ammonia beccarii & -15.4 & $1.2(0.6)$ & $0.02(0.01)$ & n.d. & n.d. & n.d. & n.d. & n.d. & n.d. \\
\hline Uncharacterized & -24.8 & $1295.8(1729.2)$ & $10.7(6.1)$ & -22.7 & $2850.9(3030.4)$ & $22.72(21.5)$ & -14.3 & $14227.3(1443.3)$ & $85.5(5.22)$ \\
\hline
\end{tabular}

most samples and were present at sufficient biomass for isotope analysis $\left(\sim 2000 \mu \mathrm{mol} \mathrm{C} \mathrm{m}^{-2}\right.$ and $\sim 1000 \mu \mathrm{mol} \mathrm{C} \mathrm{m}{ }^{-2}$, respectively). These species together accounted for $62 \pm 5 \%$ of the total mass of fauna in $0-10 \mathrm{~cm}$ sediment, but represented $<1 \%$ of the sediment OC pool (Table 1). There was a similar contribution of E. advenum and A. beccarii to total meiobenthos in $0-2(\sim 22 \%)$ and $2-5 \mathrm{~cm}$ sediment $(\sim 31 \%)$, but $E$. advenum was more abundant than $A$. beccarii in 5$10 \mathrm{~cm}$ sediments (45\% vs $34 \%$ of meiobenthos mass).

The fraction of sediment OC that was not within the compartments considered in the current study (i.e. uncharacterized OC) increased with sediment depth (Table 1). Whereas only $\sim 11 \%$ of sediment OC was uncharacterized in $0-2 \mathrm{~cm}$ sediments, we were unable to account for $\sim 23 \%$ and $\sim 86 \%$ of OC at 2-5 and 5-10 cm (Table 1).

\subsection{Natural abundance stable isotopes}

Sediment $\mathrm{OC} \delta^{13} \mathrm{C}$ values were similar for $0-2 \mathrm{~cm}$ and $2-$ $5 \mathrm{~cm}$ sediments (average $=-16.0 \%$ and $-16.3 \%$, respectively), but enriched in deeper sediments $(-14.4 \%$ ) . Values of $\delta^{13} \mathrm{C}$ for MPB and bacteria varied little with depth (Table 1 ), and $\delta^{13} \mathrm{C}$ values for bacteria were 0.5 to $2 \%$ o depleted, on average, compared to MPB (Table 1). E. advenum and A. beccarii in $0-2 \mathrm{~cm}$ sediments had $\delta^{13} \mathrm{C}$ values of $-16.4 \%$ and $-15.4 \%$, within the range of bacteria and bulk sediment OC. In contrast, $\delta^{13} \mathrm{C}$ values for uncharacterized surface sediment OC were relatively depleted $(\sim-23 \%$ o to $-25 \%$; Table 1$)$, but were more enriched in $5-10 \mathrm{~cm}$ sediments $(-14.3 \%$ o).

Control $\delta^{13} \mathrm{C}$ values of water column DOC were relatively depleted $(-30.6 \pm 0.5 \%)$. Control $\delta^{13} \mathrm{C}$ values for DIC averaged $-1.5 \pm 1.8 \%$ o throughout the study period.

\section{$3.4{ }^{13} \mathrm{C}$ incorporation, burial, and transfer}

By $12 \mathrm{~h}$ after label application $12.0 \pm 4.5 \mathrm{mmol}^{13} \mathrm{C} \mathrm{m}^{-2}$ had been incorporated into $\mathrm{OC}$ at sediment $0-10 \mathrm{~cm}$ deep, giving an uptake rate for ${ }^{13} \mathrm{C}$ of $1.0 \pm 0.4 \mathrm{mmol}^{13} \mathrm{C} \mathrm{m}^{-2} \mathrm{~h}^{-1}$. However, given that unincorporated label would have been removed with the first tidal inundation, ${ }^{13} \mathrm{C}$ uptake most likely occurred within $4 \mathrm{~h}$ of label application (before
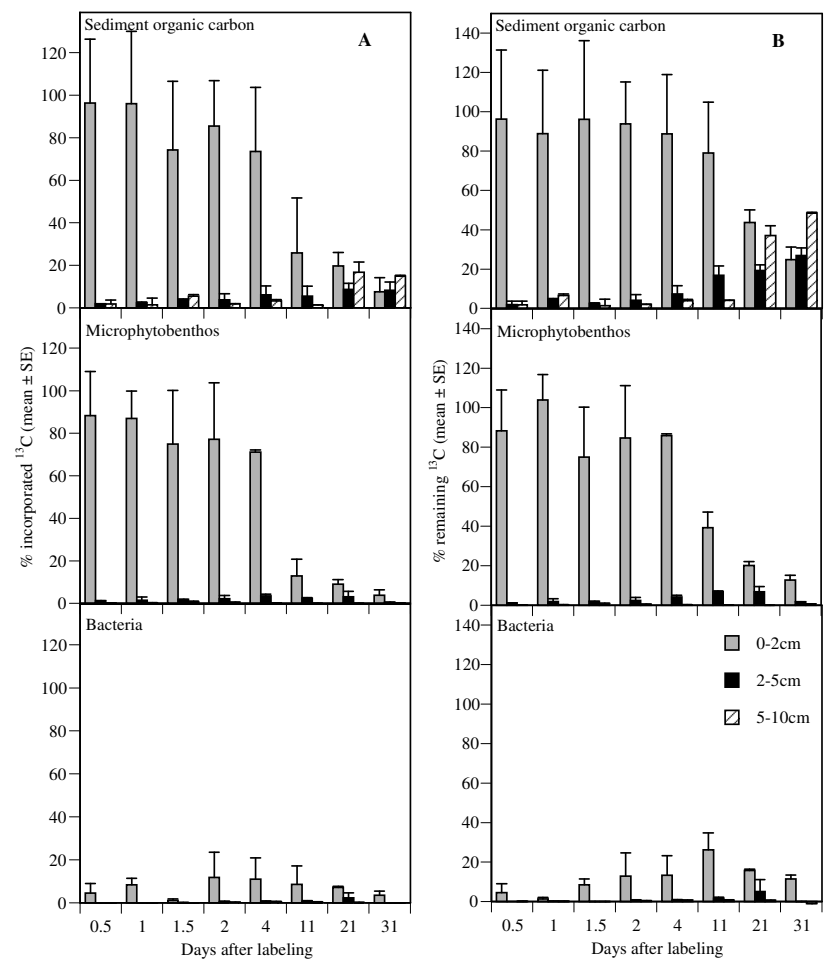

Fig. 2. Percentage (mean $\pm \mathrm{SE}, n=2$ ) of the ${ }^{13} \mathrm{C}$ that was initially incorporated by microphytobenthos (A), and percentage (mean $\pm \mathrm{SE}, n=2$ ) of the ${ }^{13} \mathrm{C}$ remaining within total sediment $\mathrm{OC}$ at each time (B), that was found within total organic carbon, microphytobenthos, and bacteria in sediment at depths of $0-2 \mathrm{~cm}, 2-5 \mathrm{~cm}$ and $5-10 \mathrm{~cm}$ throughout the study period. Days after labeling indicate time of sample collection, including time required for core incubation.

tidal inundation), giving an adjusted uptake rate of 3.0 $\pm 1.1 \mathrm{mmol}^{13} \mathrm{C} \mathrm{m}^{-2} \mathrm{~h}^{-1}$. Rates of carbon fixation at the site apparently have the potential to be far higher than this, however, as $100 \%$ of the added ${ }^{13} \mathrm{C}$ was assimilated, indicating that MPB at the site was carbon limited.

For the first $4 \mathrm{~d}$ following label addition, MPB was the major reservoir for fixed ${ }^{13} \mathrm{C}$, accounting for 77.6 to $100 \%$ 
of the total ${ }^{13} \mathrm{C}$ remaining within sediment $\mathrm{OC}$ (77.4 to $89.6 \%$ of the initially fixed ${ }^{13} \mathrm{C}$; Fig. 2a). The importance of MPB declined thereafter, however, with MPB accounting for $15.0 \%$ of the ${ }^{13} \mathrm{C}$ remaining in sediment OC (Fig. 2b), and $4.6 \%$ of the initially fixed ${ }^{13} \mathrm{C}$, by day 31 (Fig. 2a).

Despite their higher overall biomass (Table 1), bacteria had a far smaller role in ${ }^{13} \mathrm{C}$ incorporation than MPB, accounting for between 1.6 and $8.8 \%$ of the ${ }^{13} \mathrm{C}$ remaining in sediment $\mathrm{OC}$ within the first $3 \mathrm{~d}$ following label addition (Fig. 2a). Thereafter, the importance of bacteria generally increased, with bacteria accounting for a maximum of $28.4 \%$ of the ${ }^{13} \mathrm{C}$ remaining within sediment OC (Fig. $\left.2 b\right)(9.3 \%$ of fixed ${ }^{13} \mathrm{C}$; Fig. 2a) at $11 \mathrm{~d}$ after label addition.

The proportion of ${ }^{13} \mathrm{C}$ remaining in sediments that was accounted for by MPB and bacteria generally decreased during the study to $25.4 \%$ at day 31 (Fig. 2a). Fauna accounted for 0.01 to $0.03 \%$ of the ${ }^{13} \mathrm{C}$ remaining within the sediment $\mathrm{OC}$ at the times samples were analyzed $(4 \mathrm{~d}, 11 \mathrm{~d}$, and $31 \mathrm{~d}$; Fig. 2b).

There was a general increase in the ${ }^{13} \mathrm{C}$ content of deeper sediments $(2-5 \mathrm{~cm}$ and $5-10 \mathrm{~cm})$ over time (Fig. 2), but this transfer of ${ }^{13} \mathrm{C}$ to deeper sediments did not match the larger decline in ${ }^{13} \mathrm{C}$ content of surface sediments. This reflected the overall loss of ${ }^{13} \mathrm{C}$ from $0-2 \mathrm{~cm}$ sediments. The transfer of ${ }^{13} \mathrm{C}$ to deeper sediments was relatively slow; a total of $3.69 \%$ of the fixed ${ }^{13} \mathrm{C}$ was within $2-10 \mathrm{~cm}$ sediments $12 \mathrm{~h}$ after label addition, equating to a burial rate of $0.3 \% \mathrm{~h}^{-1}$. By the conclusion of the study, $75.3 \%$ of the remaining ${ }^{13} \mathrm{C}$ was within deeper sediments $(2-10 \mathrm{~cm}$; Fig. $2 b)$, representing burial over $31 \mathrm{~d}$ of around $23.2 \%$ of the ${ }^{13} \mathrm{C}$ that was initially fixed by MPB (Fig. 2a).

\section{5 $\quad{ }^{13} \mathrm{C}$ loss from sediments}

By the end of the study, $69.2 \%$ of the added ${ }^{13} \mathrm{C}$ had been lost from $0-10 \mathrm{~cm}$ sediment (Fig. 3). However, only $13.6 \%$ of the added ${ }^{13} \mathrm{C}$ was estimated to be lost via the pathways we considered, and this was almost entirely due to fluxes of ${ }^{13} \mathrm{C}$ as DIC (Fig. 3). Over the 31 day study, $1572.7 \mu \mathrm{mol}^{13} \mathrm{C} \mathrm{m}^{-2}$ $\left(13.1 \%\right.$ of added $\left.{ }^{13} \mathrm{C}\right)$ was lost from the sediment as DIC, with $\sim 80 \%$ of this loss occurring over the first $\sim 4 \mathrm{~d}$ (Fig. 3). There was generally uptake of DIC into sediment during the light $\left(2943.0 \pm 3213.374 \mu \mathrm{mol} \mathrm{m}^{-2} \mathrm{~h}^{-1}\right)$ and release during the dark $\left(1406.6 \pm 1711 \mu \mathrm{mol} \mathrm{m}{ }^{-2} \mathrm{~h}^{-1}\right)$. This corresponded with higher fluxes of ${ }^{13} \mathrm{C}$-labeled DIC in the dark than in the light.

Far less ${ }^{13} \mathrm{C}$ was lost from sediments as $\mathrm{CO}_{2}$ or DOC. DOC fluxes accounted for loss of only $58.34 \mu \mathrm{mol}{ }^{13} \mathrm{C} \mathrm{m}^{-2}$ $\left(0.48 \%\right.$ of fixed $\left.{ }^{13} \mathrm{C}\right)$. This was not surprising as there was a net uptake of DOC $\left(85.6 \pm 149.7 \mu \mathrm{mol} \mathrm{m}^{-2} \mathrm{~h}^{-1}\right)$ into sediments. In this case, losses of ${ }^{13} \mathrm{C}$ via DOC fluxes indicate an exchange of DOC between the sediment and the overlying water. DOC fluxes were highly variable, with generally smaller DOC uptake in the light $(23.9 \pm 278.0 \mu \mathrm{mol}$ $\left.\mathrm{m}^{-2} \mathrm{~h}^{-1}\right)$ than in the dark $\left(147.4 \pm 189.3 \mu \mathrm{mol} \mathrm{m}^{-2} \mathrm{~h}^{-1}\right)$.

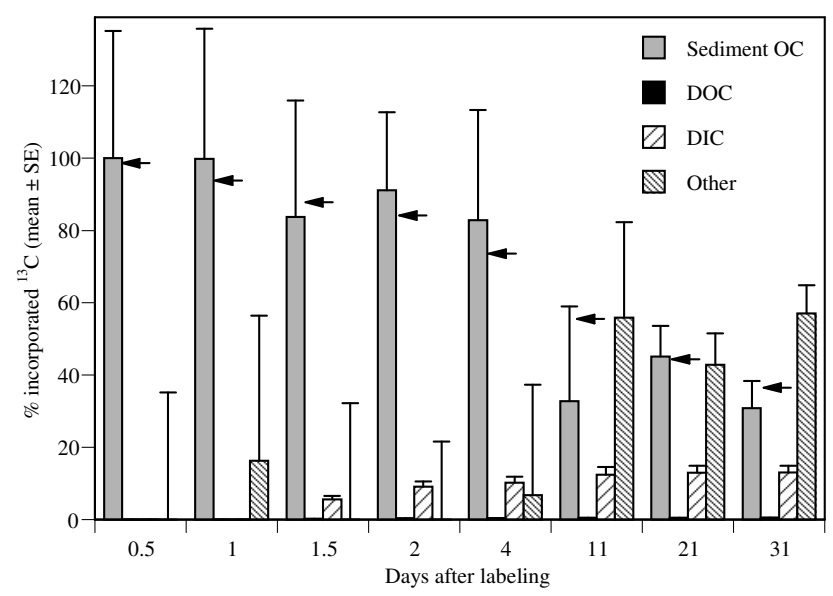

Fig. 3. Carbon budget showing cumulative percentage (mean $\pm \mathrm{SE}$, $n=2$ ) of the ${ }^{13} \mathrm{C}$ that was initially incorporated by microphytobenthos that remained in total sediment organic carbon $(0-10 \mathrm{~cm}$ depth) and that had been lost via dissolved organic carbon and dissolved inorganic carbon or via unknown pathways since the end of ${ }^{13} \mathrm{C}$-labeling. Note that fluxes of $\mathrm{CO}_{2}$ were too low to be shown. Arrows indicate ${ }^{13} \mathrm{C}$ expected to remain in total sediment organic carbon at each sampling time, based on $2-\mathrm{G}$ modeling. Days after labeling indicate time of sample collection, including time required for core incubation.

The greatest rate of loss of ${ }^{13} \mathrm{C}$ as DOC was recorded during the first dark incubation period. At all times thereafter, there was greater loss of ${ }^{13} \mathrm{C}$ as DOC in the light than in the dark.

Fluxes of $\mathrm{CO}_{2}$ were only measured for the last three time periods, but at these times the loss of ${ }^{13} \mathrm{C}$ via $\mathrm{CO}_{2}$ was only $0.2 \%$ to $5.1 \%$ of the loss of ${ }^{13} \mathrm{C}$ via DIC. Assuming that fluxes of ${ }^{13} \mathrm{C}$ in $\mathrm{CO}_{2}$ at all times represented $\sim 5 \%$ of the ${ }^{13} \mathrm{C}$ lost as DIC (the maximum observed in the current study), a total of $0.02 \%$ of the fixed ${ }^{13} \mathrm{C}\left(\sim 3 \mu \mathrm{mol}{ }^{13} \mathrm{C} \mathrm{m}^{-2}\right)$ would have been lost via fluxes of $\mathrm{CO}_{2}$ from exposed sediments.

The $55.6 \%$ of added ${ }^{13} \mathrm{C}$ that was lost from sediments and which was not accounted for by the pathways that were directly measured was assumed to represent the fraction of fixed carbon that was lost from sediments via resuspension, burial to deeper sediments than those considered here, or removal by mobile animals (Fig. 3).

The decline in ${ }^{13} \mathrm{C}$ content of $\mathrm{OC}$ in $0-10 \mathrm{~cm}$ sediments over the duration of the current study could be fitted with a $2-\mathrm{G}$ model $\left(R^{2}=0.89 \pm 0.08\right.$; Fig. 3$)$. Of the total sediment OC, $22.24 \pm 7.24 \%$ was highly reactive (fraction $G_{1}$ ), with a degradation rate $\left(k_{1}\right)$ of $\left.0.022 \pm 0.018 \mathrm{~d}^{-1}\right)$. A further $47.72 \pm 8.06 \%$ was less reactive (fraction $G_{2}$ ), degrading at a rate $\left(k_{2}\right)$ of $\left.0.002 \pm<0.001 \mathrm{~d}^{-1}\right)$. The remaining $30.03 \pm 0.82 \%$ of the sediment $\mathrm{OC}$ was nonreactive over the timescale of the experiment (fraction $G_{\mathrm{NR}}$ ). 


\section{Discussion}

\subsection{Site characteristics}

The microbial community at the study site was highly abundant; MPB and bacteria together comprised $\sim 90 \%$ of the OC in surface $\left(0-2 \mathrm{~cm}\right.$ ) sediments (Table 1). Based on $\mathrm{O}_{2}$ fluxes in control cores (assuming $\mathrm{O}_{2}: \mathrm{C}=1: 1$ and $12 \mathrm{~h}$ of production per day), the estimated GPP of the MPB community $\left(\sim 240 \mathrm{~g} \mathrm{C} \mathrm{m}^{-2} \mathrm{yr}^{-1}\right)$ was towards the upper end of values reported for MPB in intertidal and shallow coastal sediments (Colijn and de Jonge, 1984; Barranguet et al., 1998 and references therein). The productivity of the MPB was similar throughout the study despite variations in MPB biomass, but the ratio of biomass to productivity was high, indicating that turnover was slow. During the first $11 \mathrm{~d}$ of the study the turnover time of MPB was $\sim 100 \mathrm{~d}$, and even at the conclusion of the study, with $40 \%$ lower MPB biomass, the turnover time was still $\sim 66 \mathrm{~d}$. This is remarkably slow compared to estimates for temperate subtidal and intertidal sand and mud (1.3-62 d; Sundbäck et al., 1996; Middelburg et al., 2000; Evrard et al., 2010) and subtropical shallow subtidal sand and mud (0.6 to 21.7; Ferguson et al., 2003; $5.5 \mathrm{~d}$; Oakes et al., 2010b). As noted by Middelburg et al. (2000), similar rates of MPB production can correspond with substantial differences in MPB biomass. For example, MPB in subtropical shallow subtidal sediments have been reported to be similarly productive, but with far lower biomass than in the current study (Ferguson et al., 2003; Oakes et al., 2010b). This demonstrates that MPB biomass is not a reliable indicator of productivity.

The long turnover time of MPB at the study site may reflect inorganic carbon limitation and substantial recycling of fixed carbon by MPB. Inorganic carbon availability has been reported to limit primary production by MPB in laboratory studies (Admiraal et al., 1982; Cook and Røy, 2006) and epilithic microalgae in situ (coral biofilms; Larkum et al., 2003), particularly when productivity is high. At the study site, the uptake of all of the added ${ }^{13} \mathrm{C}$ suggests that inorganic carbon limited MPB productivity, at least during exposure. This probably relates to the high biomass of MPB, leading to intense competition for resources. The estimated productivity of MPB during exposure, based on ${ }^{13} \mathrm{C}$ uptake $\left(3.0 \pm 1.1 \mathrm{mmol} \mathrm{m}^{-2} \mathrm{~h}^{-1}\right)$, was similar to the productivity of inundated sediments based on $\mathrm{O}_{2}$ fluxes (see 'Site description'; $\sim 3 \mathrm{mmol} \mathrm{m}^{-2} \mathrm{~h}^{-1}$ ). This is despite the potential stimulation of the carbon-limited exposed MPB through addition of inorganic carbon. It is therefore likely that carbon limitation was greatest during exposure of the sediment and productivity of MPB during exposure is usually somewhat lower. This may reflect depletion of inorganic carbon within porewater during emersion, and limited diffusion of new $\mathrm{CO}_{2}$ into sediment porewater. Given that our estimate of GPP over the year was based on inundated fluxes, true GPP of the study site may be as low as half of that estimated, as sediments would be exposed to air for approximately half of each day.

Although MPB and bacteria represented most of the OC within surface sediments, a further $10.7 \%$ was uncharacterized. This would likely be comprised of both labile and refractory components including extracellular organic carbon exuded by MPB and bacteria, and allochthonous OC. Based on the known biomass and $\delta^{13} \mathrm{C}$ values of the total sediment OC and the measured sediment compartments (MPB, bacteria, and fauna), isotope mixing suggests a $\delta^{13} \mathrm{C}$ value for uncharacterized OC of $\sim-25 \%$ o (Table 1). This is within the range of $\delta^{13} \mathrm{C}$ values for phytoplankton and terrestrial plants (Michener and Schell, 1994), confirming a contribution of allochthonous OC. Given the relatively depleted natural abundance $\delta^{13} \mathrm{C}$ value for DOC at the site $(\sim-30 \%$ o), allochthonous OC may also be the source of the DOC released from control sediments. The relatively high $\mathrm{C}: \mathrm{N}$ ratio of sediment OC was well above a typical Redfield ratio. This could reflect substantial re-working of sediment OC, leading to enrichment of the $\mathrm{C}: \mathrm{N}$ ratio, but more likely reflects a contribution of terrestrial material, as episodic rainfall events increase the flow of freshwater at the study site, and can enhance the delivery of terrestrial OC (Eyre and Twigg, 1997). Given the dominance of fine particles in the surficial sediments at the study site, some of this is likely to be derived from recent deposition of terrigenous sediments following the flood events. This deposition of new material would offset losses of OC and is reflected in the lower apparent rate of loss of total OC from sediments ( $25 \%$ ) compared to MPB $(40 \%)$ and bacteria $(45 \%)$.

The contribution of uncharacterized OC to the total sediment pool increased with sediment depth (Table 1), but its source was less clear. The $\delta^{13} \mathrm{C}$ value of uncharacterized OC was considerably enriched in deeper $(5-10 \mathrm{~cm})$ sediments (Table 1), suggesting that there has been (i) burial of MPB-derived carbon; (ii) burial of relatively ${ }^{13} \mathrm{C}$-enriched allochthonous OC (e.g. seagrass; Jones et al,. 2003), or substantial re-working of OC resulting in preferential removal of ${ }^{12} \mathrm{C}$, or ${ }^{13} \mathrm{C}$-depleted compounds (e.g. lipids; DeNiro and Epstein, 1977).

Given the considerable contribution of bacteria to sediment OC at all sediment depths (11.6\% to $53.6 \%$ of total OC), they are likely to be the main contributor to carbon processing at the study site. The relatively enriched $\delta^{13} \mathrm{C}$ values of bacteria suggested that there was a substantial contribution of MPB-derived carbon, but the uncharacterized OC fraction also contributed, leading to the depletion of $\delta^{13} \mathrm{C}$ values for bacteria compared to MPB. Assuming a trophic fractionation of $0.5 \%$ for carbon (McCutchan et al., 2003), MPB and the uncharacterized $\mathrm{OC}$ fraction contributed 82.9 and $17.1 \%$, respectively, of the carbon for bacteria in $0-2 \mathrm{~cm}$ sediments, and 74.2 and $25.8 \%$ in $2-5 \mathrm{~cm}$ sediments. The carbon source for bacteria in $5-10 \mathrm{~cm}$ sediment could not be resolved, as the $\delta^{13} \mathrm{C}$ value was depleted compared to both potential sources. However, given the greater biomass of bacteria in shallow 
sediment, the $\delta^{13} \mathrm{C}$ value of bacteria in $5-10 \mathrm{~cm}$ sediments was likely dominated by bacteria towards the upper extent of this layer, which would have access to more depleted uncharacterized OC (Table 1).

\section{2 ${ }^{13} \mathrm{C}$ transfer and burial}

Given that an earlier study $\sim 120 \mathrm{~km}$ north of the site of the current study showed that there was no carbon fixation in muddy or sandy sediments in the dark (Oakes, 2007), all ${ }^{13} \mathrm{C}$ within the sediments was assumed to have been initially fixed by MPB. There was rapid transfer of ${ }^{13} \mathrm{C}$ to heterotrophs, with $4.5 \%$ of the fixed ${ }^{13} \mathrm{C}$ found within bacteria $12 \mathrm{~h}$ after label addition, but the total quantity of ${ }^{13} \mathrm{C}$ transferred was limited. Throughout the study, only $1.2 \%$ to $12.5 \%$ of the total fixed ${ }^{13} \mathrm{C}$ was found in bacteria, and up to $0.01 \%$ in fauna. At best, $28.4 \%$ of the ${ }^{13} \mathrm{C}$ remaining within sediment $\mathrm{OC}$ at any one time was within bacteria (at $11 \mathrm{~d}$ ), but this only equated to just over half of the ${ }^{13} \mathrm{C}$ within MPB at this time. This was similar to the proportion of remaining fixed carbon that was in bacteria $11 \mathrm{~d}$ after ${ }^{13} \mathrm{C}$-labeling of MPB in subtropical subtidal sands (Oakes et al., 2010b). However, whereas this and a number of other studies (Middelburg et al., 2000; Woulds et al., 2007; Oakes et al., 2010b) have found ${ }^{13} \mathrm{C}$ incorporation by sediment compartments to be roughly proportional to biomass this was not the case in the current study. Whereas the biomass of MPB and bacteria were similar in $0-2 \mathrm{~cm}$ sediments, the majority of fixed ${ }^{13} \mathrm{C}$ within sediments was in MPB at all sampling times. Even in the $2-5 \mathrm{~cm}$ sediments, where bacterial biomass exceeded that of MPB, MPB contained a greater portion of ${ }^{13} \mathrm{C}$ at all times. Until at least $4 \mathrm{~d}$ after label addition, $78 \%$ or more of the ${ }^{13} \mathrm{C}$ remaining within sediment $\mathrm{OC}$ was within MPB, and by the end of the study (at $31 \mathrm{~d}$ ) $15 \%$ of the ${ }^{13} \mathrm{C}$ was still within MPB. This corresponds with the slow turnover rate estimated for MPB. An exponential curve fitted to the data $\left(R^{2}=0.98\right)$ predicted that ${ }^{13} \mathrm{C}$ would remain within MPB until $>80 \mathrm{~d}$ after label addition (Fig. 4).

Possible explanations for the apparent slow turnover and ${ }^{13} \mathrm{C}$ retention of MPB include (i) substantial recycling of fixed carbon by MPB via mobilization of their own EPS (Stal 2003) or internal storage compounds (Bellinger et al., 2009), (ii) limited grazing of MPB by higher heterotrophs (supported by low biomass and ${ }^{13} \mathrm{C}$ content of fauna), and (iii) efficient recapture of ${ }^{13} \mathrm{C}$ remineralized by bacteria, but most likely relates to (iv) limited production of EPS. A substantial portion of the carbon fixed by MPB can be rapidly exuded as EPS (up to $70.3 \% \mathrm{~h}^{-1}$; Goto et al., 1999). In the current study, however, only $10.5 \%$ of the ${ }^{13} \mathrm{C}$ within sediment OC had been transferred from MPB to bacteria and/or DOC within $12 \mathrm{~h}$, equating to an EPS production rate at the lower end of the range reported for marine benthic diatoms and sediment biofilms $\left(0.9 \% \mathrm{~h}^{-1}\right.$; Underwood and Paterson, 2003). Given that EPS can play an important role in the transfer of carbon from autotrophs to heterotrophs (Oakes

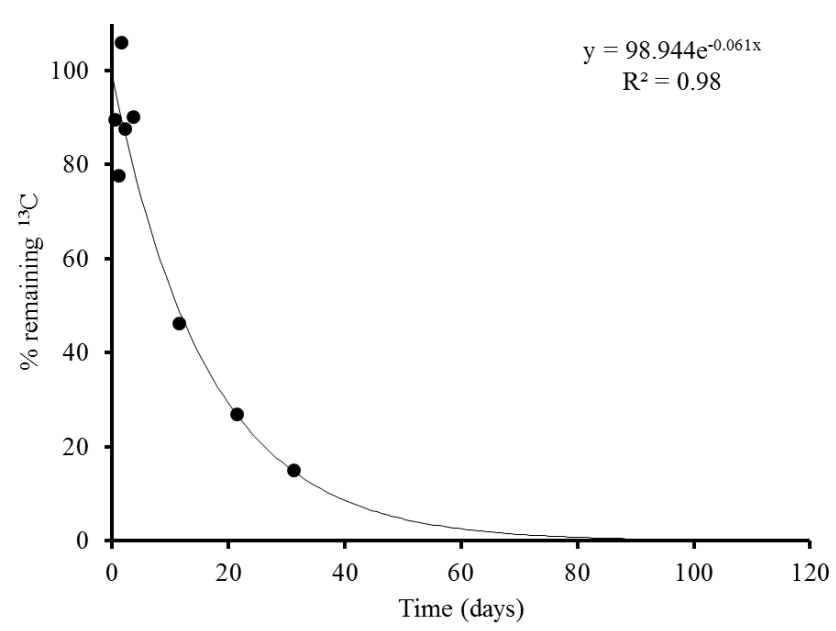

Fig. 4. Exponential curve predicting percentage of ${ }^{13} \mathrm{C}$ remaining in sediment organic carbon that is expected to be within MPB over time. Data points show values measured over the 31 day study.

et al., 2010b), low production of EPS is likely to have contributed to the limited transfer of ${ }^{13} \mathrm{C}$ to bacteria and higher heterotrophs (Fig. 5). The production of EPS assists with diatom movement and attachment and increases with nutrient limitation (Cook et al., 2007), functioning to maintain Redfield $\mathrm{C}: \mathrm{N}$ whilst protecting cells from potential damage by excess energy (Stal, 2003). Around the time of the current study, rain events most likely ensured that nutrients were in plentiful supply, both in the water column and in sediments, due to degradation of recently deposited allochthonous material. Excessive production of EPS by MPB would therefore be unnecessary and, given that inorganic carbon availability is sometimes limited, may be undesirable. Rather, it is possible that fixed carbon is stored intracellularly as chrysolaminarin (Bellinger et al., 2009), for use when carbon limits MPB production (e.g. during exposure; Fig. 5).

Although $75.3 \%$ of the ${ }^{13} \mathrm{C}$ remaining at the end of the study ( $31 \mathrm{~d}$ ) was in sediments at $2-10 \mathrm{~cm}$ depth, representing $23.2 \%$ of the ${ }^{13} \mathrm{C}$ that was initially fixed, the rate of downward transport of ${ }^{13} \mathrm{C}$ was slower than has been seen in previous studies. Oakes et al. (2012) observed transfer of $12.9 \%$ of fixed carbon to $2-5 \mathrm{~cm}$ and $18.6 \%$ to $5-10 \mathrm{~cm}$ within $60 \mathrm{~h}$ in shallow subtidal subtropical sands, and Middelburg et al. (2000) and Evrard et al. (2010) reported similar transport of fixed carbon to $2-5 \mathrm{~cm}$ in temperate mud and sand within $3 \mathrm{~d}$. However, in the current study a far smaller proportion of the initially fixed ${ }^{13} \mathrm{C}$ was at these depths even $31 \mathrm{~d}$ after label addition ( $8.3 \%$ and $14.9 \%$ to $2-5 \mathrm{~cm}$ and $5-10 \mathrm{~cm}$, respectively). In contrast to our earlier study of subtidal sands (Oakes et al., 2012), there was considerable removal of ${ }^{13} \mathrm{C}$ via resuspension in the current study, possibly reflecting differences in water depth and/or the absence of substantial freshwater input during the previous study. The resuspension of organic carbon in the current study would have limited the 


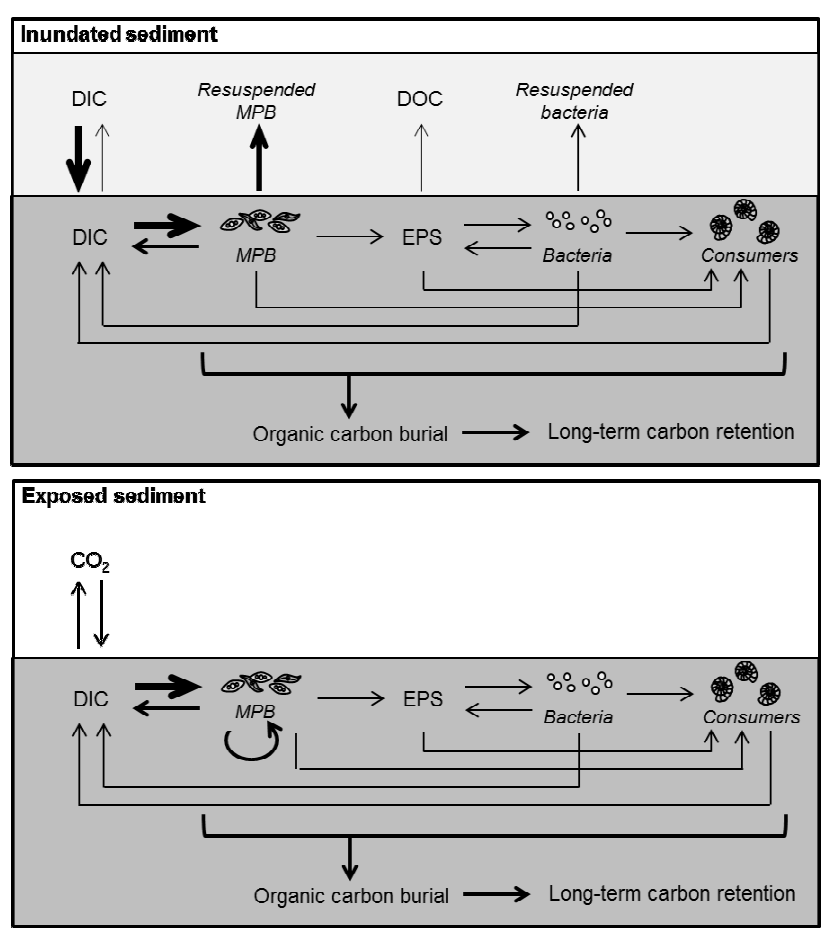

Fig. 5. Conceptual model showing pathways for the transfer of carbon fixed by microphytobenthos in the subtropical intertidal sediments investigated in this study during inundation and exposure. Thicker arrows indicate pathways that, in the current study, were determined or estimated to be more dominant over 31 days.

pool of ${ }^{13} \mathrm{C}$ available for downward transport (Fig. 5). The low biomass of fauna would also have limited the potential for carbon burial through bioturbation, subduction, and consumption by mobile animals. However, the intertidal study of Middelburg et al. (2000) also reported substantial loss of fixed carbon via resuspension, but had greater burial. Sediment flushing and mixing, which is influenced by sediment porosity and tidal movement, can transport fixed carbon to deeper sediments. The grain size of our sediment was intermediate to that of sediment at two sites studied by Middelburg et al. (2000). However, the tidal amplitude $(\sim 5 \mathrm{~m})$ at the site studied by Middelburg et al. (2000) was far greater than in the current study $(\sim 2 \mathrm{~m})$. Although this would have contributed to sediment resuspension, this may also have enhanced sediment mixing and, therefore, burial of carbon that had not been resuspended. Increased flow rates and scouring at the time of the current study may also have reduced the potential for new sediments to deposit at the study site, thereby limiting burial through this mechanism.

\section{$4.3{ }^{13} \mathrm{C}$ loss}

An important attribute of this study is that the ${ }^{13} \mathrm{C}$-labeled sediment community was exposed to natural environmental conditions for the majority of the study, allowing for natural loss processes to occur. The overall loss of ${ }^{13} \mathrm{C}$ from sediments and the budget for loss and retention over the duration of the study therefore incorporates the effect of these in situ processes. A further characteristic of the current study is that it is one of very few (e.g. Oakes et al., 2012) to have directly measured so many loss pathways. However, we were still unable to account for loss of $\sim 50 \%$ of the carbon initially fixed by MPB. This carbon was most likely lost via resuspension of surface sediment OC, particularly given the elevated freshwater flow rates at the study site, but this was not directly quantified in the current study. Although burial to sediments below $10 \mathrm{~cm}$ and/or removal by mobile consumers are also possible pathways for loss that were not considered, the general lack of fauna in the sediments and limited burial of ${ }^{13} \mathrm{C}$ below $5 \mathrm{~cm}$ suggests that these pathways are probably relatively minor contributors to carbon loss.

The lack of fauna in the system is likely to have had a significant impact on the processing and fate of MPB carbon, by reducing burial and grazing. Although the low biomass of fauna may relate to highly variable environmental conditions (e.g. episodic freshwater inputs), which is typical of this and other (sub) tropical systems (Eyre and Twigg, 1997; Eyre, 2000), it is also typical of intertidal sediments in tropical systems in general (Purwoko and Wolff, 2008). It should be noted that where macrofauna is more abundant the retention of MPB carbon may be greater, due to enhanced burial, or reduced due to increased grazing and respiration.

Resuspension of sediment and associated material, including MPB, is generally driven by wind- or tide-generated turbulence (de Jonge and van Beusekom, 1995), but in the current study was probably also strongly driven by enhanced freshwater flow rates following a rain event (Eyre and Twigg, 1997). The potential importance of these rain events is demonstrated in the discrepancy between the quantity of ${ }^{13} \mathrm{C}$ measured within sediment $\mathrm{OC}$ and the higher value predicted by $2-G$ modeling, shortly after a rain event (11 days after labeling, Fig. 4). However, given that estimated and measured quantities of ${ }^{13} \mathrm{C}$ in sediment $\mathrm{OC}$ were more similar thereafter, it appears that removal of ${ }^{13} \mathrm{C}$ may be spatially heterogeneous. Significant episodic freshwater flows are typical of any (sub) tropical systems (Eyre, 1998; Eyre and Balls, 1999; Eyre, 2000). However, it is likely that a smaller portion of the carbon fixed by MPB would be lost from sediments via resuspension under drier conditions. Similarly, a larger proportion of the carbon fixed by MPB would be lost from sediments via resuspension during larger floods (see Eyre and Twigg, 1997; Eyre, 2000) and scouring of sediments may remove deeper sediments, reducing longer term carbon storage potential.

The susceptibility of surface sediments to resuspension depends on a number of factors including water depth and flow rate, tidal height, activity of fauna and characteristics of the sediment including the presence or absence of a stabilizing biofilm (MacIntyre et al., 1996). In intertidal sediments, tidal movements can cause resuspension of a substantial part of the MPB community (up to $50 \%$ or more 
in temperate mudflats; de Jonge and van Beusekom, 1995) and EPS ( $60 \%$; Hanlon et al., 2006). Migration of MPB can buffer against their resuspension, but given that MPB were the major reservoir for fixed carbon throughout the current study, and there was similar loss of MPB and bacterial biomass from the sediments, it is likely that resuspension of MPB was the major conduit for loss of fixed carbon via this pathway. Alternatively, resuspension may have removed EPS before it was assimilated by heterotrophs.

Few studies have specifically assessed rates of loss of MPB-derived carbon from sediment. In subtropical subtidal sands, we saw very little loss of fixed carbon from subtidal sands via resuspension over 30 days in a previous study $(<$ $3 \%$; Oakes et al., 2012). In contrast, Middelburg et al. (2000) reported loss via resuspension of $34 \%$ of carbon fixed by MPB from intertidal sands within $5.6 \mathrm{~d}$, reflecting the influence of the turbid tidal edge. Although we observed similar loss of fixed carbon overall in subtropical intertidal sediments in the current study, the rate of loss was slower, occurring primarily over $11 \mathrm{~d}$. As discussed previously, this may relate to the lower tidal movement at the site of the current study, compared to that at the site studied by Middelburg et al. (2000). Given that losses due to resuspension were almost certainly enhanced by elevated river flows in the current study, it is likely that the loss to resuspension would be lower again under more typical flow conditions. Although other factors may also be important, the pattern of faster loss of MPB carbon with increased tidal movement across three studies (Middelburg et al., 2000; Oakes et al., 2012; current study) suggests that tidal movement has a major influence on MPB carbon fate.

Of the pathways measured directly, DIC flux during inundation was the most important for loss of carbon fixed by MPB (Fig. 5), but still accounted for only $\sim 19 \%$ of the total lost ${ }^{13} \mathrm{C}$, or $\sim 13 \%$ of the carbon that was initially fixed. In temperate and subtropical subtidal sands, respiration has been reported to have a greater contribution to removal of MPB-derived carbon (14\% over $4 \mathrm{~d}$ and $63 \%$ over $30 \mathrm{~d}$; Evrard et al., 2010; Oakes et al., 2012). This difference is not surprising, given the considerable removal of fixed carbon by resuspension in the current study, which would limit the carbon available for respiration. However, in temperate intertidal sands that are similarly susceptible to resuspension, respiration was estimated to account for $40 \%$ of the total loss of MPB-derived carbon, although it should be noted that this was not measured directly (Middelburg et al., 2000). The limited role of respiration for transformation and loss of MPB-derived carbon in the current study site is further evidence that limited MPB-derived carbon is transferred to heterotrophs, including bacteria, over at least $31 \mathrm{~d}$. The contribution of recycling to the retention of carbon by MPB is supported by the reduced flux of ${ }^{13} \mathrm{C}$-labeled DIC in the light, particularly early in the study. This clearly reflects the re-capture of respired MPB-derived carbon by MPB for use in photosynthesis and would contribute to the apparent slow turnover of MPB and long-term retention of MPB-derived carbon within the sediment.

Fluxes of DOC were a relatively minor contributor to loss of MPB-derived carbon in the current study (Fig. 5). Given that tidal flushing and resuspension can remove a substantial portion of the EPS produced by MPB (e.g. 60\%; Hanlon et al., 2006), our ex situ core incubations may have underestimated DOC fluxes. However, this is unlikely, given the apparently low rate of EPS production. Furthermore, the two studies that have specifically considered this loss pathway (in temperate and subtropical shallow subtidal sands, respectively; Cook et al., 2007; Oakes et al., 2012) also reported limited loss of MPB-derived carbon via DOC fluxes. This may reflect rapid use of DOC within the sediment by bacteria, particularly in the current study, due to the greater bacterial biomass typical of more tropical sediments, and intense competition for labile EPS due to its limited production.

Fluxes of $\mathrm{CO}_{2}$ from sediments exposed at low tide are a further potential loss pathway but contributed very little to loss of MPB-derived carbon in the current study (up to $5 \%$ of DIC fluxes at the times measured; Fig. 5). Differences in fluxes of inorganic carbon from intertidal sediments during inundation and exposure may relate to variations in the activity of fauna during the tidal cycle. For example, bioirrigation by fauna occurs only during tidal inundation and can enhance exchange of solutes between sediment and the overlying water (Forster et al., 1999; Hedman et al., 2011). At the site of the current study, however, little macrofauna was observed at the site, and variations in the activity of biota are therefore unlikely to explain the differences in fluxes of DIC and $\mathrm{CO}_{2}$ from inundated and exposed sediments. Chemical factors offer a more likely explanation. Whereas only $\mathrm{CO}_{2}$ is released from sediments during exposure, DIC consists of $\mathrm{CO}_{2}, \mathrm{HCO}_{3}^{-}$and $\mathrm{CO}_{3}^{2-}$, all of which be transferred to overlying water (Cook et al., 2004). Therefore, if the production of DIC is constant across a tidal cycle, the ability of a greater fraction of DIC to transfer to water could lead to greater fluxes of inundated DIC than exposed $\mathrm{CO}_{2}$ from intertidal sediments. However, the few studies that have compared fluxes of $\mathrm{CO}_{2}$ and DIC from intertidal sediments during exposure and inundation have produced variable results. Whereas Gribsholt and Kristensen (2003), Cook et al. (2004), and Faber et al. (2012) all found that exposed $\mathrm{CO}_{2}$ fluxes were at least $\sim 2 \times$ lower than inundated DIC fluxes in unvegetated sediments, Alongi et al. (1999) found little difference in tropical intertidal sediments, and Gribsholt and Kristensen (2003) found that exposed $\mathrm{CO}_{2}$ fluxes were higher than inundated DIC fluxes in a vegetated marsh. In the current study, we saw very little loss of ${ }^{13} \mathrm{C}$ via $\mathrm{CO}_{2}$ fluxes compared to DIC fluxes. However, it should be noted that previous studies have looked at total fluxes of DIC and $\mathrm{CO}_{2}$, whereas we are comparing fluxes derived from recent (within $31 \mathrm{~d}$ ) MPB carbon fixation. Regardless, even assuming that fluxes of $\mathrm{CO}_{2}$ were half as important as fluxes of DIC, as reported for bare sediments (Gribsholt and Kristensen, 2003; 
Cook et al., 2004), $\mathrm{CO}_{2}$ fluxes would still only account for loss of $\sim 6.5 \%$ of the ${ }^{13} \mathrm{C}$ initially fixed by MPB over $31 \mathrm{~d}$.

\subsection{Carbon storage implications}

Despite differences in carbon processing pathways, particularly the influence of resuspension, we observed similar substantial retention of MPB-derived carbon in subtidal (Oakes et al., 2010b; Oakes et al., 2012) and intertidal subtropical sites (this study; Fig. 5). Approximately $30 \%$ of the carbon that had been fixed by the MPB community in each of these environments within one exposed period was still present within sediment $\mathrm{OC}$ after $\sim 30 \mathrm{~d}$. In the current study, $75.3 \%$ of this remaining carbon had been buried below $2 \mathrm{~cm}$, suggesting that there could be a substantial contribution of MPB to long-term carbon sequestration in unvegetated sediments. This is particularly remarkable given that the burial and retention of MPB-derived carbon in the current study was observed under conditions of high flow, when resuspension would be enhanced. This clearly demonstrates the potential of MPB in subtropical sediments to contribute to coastal carbon storage. In unvegetated sediments, scouring of sediment following rain events has the potential to limit longer term storage of MPB carbon, but this will depend on the depth of sediment removed, and the subsequent processing and fate of this resuspended carbon (e.g. re-deposition or respiration). Given the high productivity of MPB, and the potential for their carbon to be buried, it should also be considered that MPB may contribute to carbon storage in more stable, vegetated sediments.

Only two previous studies of which we are aware (Oakes et al., 2010b; Oakes et al., 2012) have considered the processing of MPB-derived carbon over such an extended time period $(\sim 30 \mathrm{~d})$. However, a comparison of the ${ }^{13} \mathrm{C}$ remaining in sediments at the end of shorter term studies with the ${ }^{13} \mathrm{C}$ remaining at a similar time in the longer term studies shows that there is some variation in carbon retention. Whereas we estimate that $\sim 75 \%$ of the ${ }^{13} \mathrm{C}$ incorporated in our study remained in sediments after $4 \mathrm{~d}$, Middelburg et al. (2000) found $\sim 67 \%$ of MPB-derived carbon remaining in temperate intertidal mud and $\sim 20 \%$ in temperate intertidal sand after a similar time. In the study by Bellinger et al. (2009), $\sim 60 \%$ of the carbon fixed by MPB remained within muds after $36 \mathrm{~h}$, although there was not a clear trend of carbon loss over time. The greater carbon retention we observed in subtropical sediments may reflect the higher productivity and/or biomass of bacteria in warmer climate sediments, leading to greater recycling of MPB-derived carbon. There is currently considerable interest in carbon burial in coastal ecosystems ("Blue Carbon"; Duarte et al., 2005; McLeod et al., 2011; Duarte et al., 2013), but the potential of MPB to contribute to this has not been considered. Most of the Blue Carbon work has focused on seagrass, mangroves and salt marsh, but MPB may also have contributed to some of carbon buried in these systems. In the current study, the retention of a substan- tial portion of fixed carbon after $31 \mathrm{~d}(30.0 \%)$, with most of this $(75.3 \%)$ buried below $2 \mathrm{~cm}$, suggests that MPB in subtropical intertidal sediments have the potential to contribute substantially to carbon burial in unvegetated sediments. Considering that previous studies in a variety of sediment types (intertidal or subtidal, muddy or sandy) and in both temperate and subtropical regions have also shown that carbon fixed by MPB within hours remains within sediments after a number of days, and because light reaches $33 \%$ of the global shelf area (Gattuso et al., 2006), the contribution of MPB to carbon storage may be widespread and warrants further investigation.

Acknowledgements. We thank Iain Alexander for field assistance, Kym Haskins and Max Johnston for extraction of biomarkers, Melissa Gibbes for fauna extraction, and Matheus Carvalho for isotope analysis. Ideas on carbon burial in this paper drew inspiration from the CSIRO Marine and Coastal Carbon Biogeochemistry Cluster. This study was funded by Australian Research Council (ARC) Discovery grants to B.D.E. (DP0663159) and B.D.E., and J.M.O. (DP0878568), an ARC Linkage grant to B.D.E. (LP0667449), ARC Linkage Infrastructure, Equipment and Facilities grants to B.D.E. and J.M.O. (LE0989952, LE0668495), and an ARC Discovery Early Career Researcher Award to J.M.O. (DE120101290).

Edited by: J. Middelburg

\section{References}

Admiraal, W., Peletier, H., and Zomer, H.: Observations and experiments on the population dynamics of epipelic diatoms from an estuarine mudflat, Estuar. Coast. Shelf S., 14, 471-487, 1982.

Agustí, S. and Duarte, C. M.: Phytoplankton lysis predicts dissolved organic carbon release in marine plankton communities, Biogeosciences, 10, 1259-1264, doi:10.5194/bg-10-1259-2013, 2013.

Alongi, D. M.: The role of bacteria in nutrient recycling in tropical mangrove and other coastal benthic ecosystems, Hydrobiologia, 285, 19-32, 1994.

Alongi, D. M., Tirendi, F., Dixon, P., Trott, L. A., and Brunskill, G. J.: Mineralization of organic matter in intertidal sediments of a tropical semi-enclosed delta, Estuar. Coast. Shelf S., 48, 451-467, 1999.

Barranguet, C., Kromkamp, J., and Peene, J.: Factors controlling primary production and photosynthetic characteristics of intertidal microphytobenthos, Mar. Ecol.-Prog. Ser., 173, 117-126, 1998.

Bellinger, B. J., Underwood, G. J. C., Ziegler, S. E., and Gretz, M. R.: Significance of diatom-derived polymers in carbon flow dynamics within estuarine biofilms determined through isotopic enrichment, Aquat. Microb. Ecol., 55, 169-187, 2009.

Boschker, H. T. S., De Brouwer, J. F. C., and Cappenberg, T. E.: The contribution of macrophyte-derived organic matter to microbial biomass in salt-marsh sediments: Stable carbon isotope analysis of microbial biomarkers, Limnol. Oceanogr., 44, 309-319, 1999. 
Colijn, F. and de Jonge, V. N.: Primary production of microphytobenthos in the Ems-Dollard Estuary, Mar. Ecol.-Prog. Ser., 14, 185-196, 1984.

Cook, P. L. M., Butler, E. C. V., and Eyre, B. D.: Carbon and nitrogen cycling on intertidal mudflats of a temperate Australian estuary. I. Benthic metabolism, Mar. Ecol.-Prog. Ser., 280, 2538, 2004.

Cook, P. L. M. and Røy, H.: Advective relief of $\mathrm{CO}_{2}$ limitation in microphytobenthos in highly productive sandy sediments, Limnol. Oceanogr., 51, 1594-1601, 2006.

Cook, P. L. M., Veuger, B., Böer, S., and Middelburg, J. J.: Effect of nutrient availability on carbon and nitrogen incorporation and flows through benthic algae and bacteria in near-shore sandy sediment, Aquat. Microb. Ecol., 49, 165-180, 2007.

de Jonge, V. N. and van Beusekom, J. E. E.: Wind- and tide-induced resuspension of sediment and microphytobenthos from tidal flats in the Ems estuary, Limnol. Oceanogr., 40, 766-778, 1995.

DeNiro, M. J. and Epstein, S.: Mechanism of carbon isotope fractionation associated with lipid synthesis, Science, 197, 261-263, 1977.

Duarte, C. M., Middelburg, J. J., and Caraco, N.: Major role of marine vegetation on the oceanic carbon cycle, Biogeosciences, 2, 1-8, doi:10.5194/bg-2-1-2005, 2005.

Duarte, C. M., Kennedy, H., Marbà, N., and Hendriks, I.: Assessing the capacity of seagrass meadows for carbon burial: current limitations and future strategies, Ocean Coast. Manage., 83, 32-38, 2013.

Evrard, V., Cook, P. L. M., Huettel, M., and Middelburg, J. J.: Tracing carbon and nitrogen incorporation and pathways in the microbial community of a photic subtidal sand, Aquat. Microb. Ecol., 53, 257-269, 2008.

Evrard, V., Soetaert, K., Heip, C. H. R., Huettel, M., Xenopoulos, M. A., and Middelburg, J. J.: Carbon and nitrogen flows through the benthic food web of a photic subtidal sandy sediment, Mar. Ecol.-Prog. Ser., 416, 1-16, 2010.

Evrard, V., Huettel, M., Cook, P. L. M., Soetaert, K., Heip, C. H. R., and Middelburg, J. J.: Importance of phytodetritus and microphytobenthos for heterotrophs in a shallow subtidal sandy sediment, Mar. Ecol.-Prog. Ser., 455, 13-31, 2012.

Eyre, B. D., and Twigg, C.: Nutrient behaviour during post-flood recovery of the Richmond River Estuary Northern NSW, Australia, Estuar. Coast. Shelf. S., 44, 311-326, 1997.

Eyre, B.: Transport, retention and transformation of material in Australian estuaries, Estuaries, 21, 540-551, 1998.

Eyre, B. and Balls, P.: A comparative study of nutrient behavior along the salinity gradient of tropical and temperate estuaries, Estuaries, 22, 313-326, 1999.

Eyre, B. D.: Regional evaluation of nutrient transformation and phytoplankton growth in nine river-dominated sub-tropical east Australian estuaries, Mar. Ecol.-Prog. Ser., 205, 61-83, 2000.

Faber, P. A., Kessler, A. J., Bull, J. K., McKelvie, I. D., Meysman, F. J. R., and Cook, P. L. M.: The role of alkalinity generation in controlling the fluxes of $\mathrm{CO}_{2}$ during exposure and inundation on tidal flats, Biogeosciences, 9, 4087-4097, doi:10.5194/bg-9-4087-2012, 2012.

Ferguson, A. J. P., Eyre, B. D., and Gay, J. M.: Organic matter and benthic metabolism in euphotic sediments along shallow subtropical estuaries, northern New South Wales, Australia, Aquat. Microb. Ecol., 33, 137-154, 2003.
Forster, S., Glud, R. N., Gundersen, J. K., and Huettel, M.: In situ study of bromide tracer and oxygen flux in coastal sediments, Estuar. Coast. Shelf S., 49, 813-827, 1999.

Gattuso, J.-P., Gentili, B., Duarte, C. M., Kleypas, J. A., Middelburg, J. J., and Antoine, D.: Light availability in the coastal ocean: impact on the distribution of benthic photosynthetic organisms and their contribution to primary production, Biogeosciences, 3, 489-513, doi:10.5194/bg-3-489-2006, 2006.

Goto, N., Kawamura, T., Mitamura, O., and Terai, H.: Importance of extracellular organic carbon production in the total primary production by tidal-flat diatoms in comparison to phytoplankton, Mar. Ecol.-Prog. Ser., 190, 289-295, 1999.

Goto, N., Mitamura, O., and Terai, H.: Biodegradation of photosynthetically produced extracellular organic carbon from intertidal benthic algae, J. Exp. Mar. Biol. Ecol., 257, 73-86, 2001.

Gribsholt, B. and Kristensen, E.: Benthic metabolism and sulfur cycling along an inundation gradient in a tidal Spartina anglica salt marsh, Limnol. Oceanogr., 48, 2151-2162, 2003.

Hanlon, A. R. M., Bellinger, B., Haynes, K., Xiao, G., Hofmann, T. A., Gretz, M. R., Ball, A. S., Osborn, A. M., and Underwood, G. J. C.: Dynamics of extracellular polymeric substance (EPS) production and loss in an estuarine, diatom-dominated, microalgal biofilm over a tidal emersion-immersion period, Limnol. Oceanogr., 51, 79-93, 2006.

Hedman, J. E., Gunnarsson, J. S., Samuelsson, G., and Gilbert, F.: Particle reworking and solute transport by the sediment-living polychaetes Marenzelleria neglecta and Hediste diversicolor, J. Exp. Mar. Biol. Ecol., 407, 294-301, 2011.

Heip, C. H. R., Goosen, N. K., Herman, P. M. J., Kromkamp, J., Middelburg, J. J., and Soetaert, K.: Production and consumption of biological particles in temperate tidal estuaries, Oceanogr. Mar. Biol., 33, 1-150, 1995.

Jones, W. B., Cifuentes, L. A., and Kaldy, J. E.: Stable carbon isotope evidence for coupling between sedimentary bacteria and seagrasses in a sub-tropical lagoon, Mar. Ecol.-Prog. Ser., 255, 15-25, 2003.

Larkum, A. W. D., Koch, E. C., and Kühl, M.: Diffusive boundary layers and photosynthesis of the epilithic algal community of coral reefs, Mar. Biol., 142, 1073-1082, 2003.

MacIntyre, H. L., Geider, R. J., and Miller, D. C.: Microphytobenthos - the ecological role of the secret garden of unvegetated, shallow-water marine habitats, I. Distribution, abundance and primary production, Estuaries, 19, 186-201, 1996.

Maher, D. T., Santos, I. R., Carvalho, M. C., Leuven, J. R. F. W., Oakes, J. M., Erler, D. V., and Eyre, B. D.: Novel use of cavity ring-down spectroscopy to investigate aquatic carbon cycling from microbial to ecosystem scales, Environ. Sci. Technol., 47, 12938-12945, 2013.

McCutchan, J. H., Lewis, W. M., Kendall, C., and McGrath, C. C.: Variation in trophic shift for stable isotope ratios of carbon, nitrogen, and sulfur, Oikos, 102, 378-390, 2003.

McKee, L. and Eyre, B. D.: Nitrogen and phosphorus budgets for the sub-tropical Richmond River catchment, Australia, Biogeochemistry, 50, 207-239, 2000.

McLeod, E., Chmura, G. L., Bouillon, S., Salm, R., Björk, M., Duarte, C. M., Lovelock, C. E., Schlesinger, W. H., and Silliman, B. R.: A blueprint for blue carbon: toward an improved understanding of the role of vegetated coastal habitats in sequestering $\mathrm{CO}_{2}$, Front. Ecol. Environ., 9, 552-560, 2011. 
Michener, R. H. and Schell, D. M.: Stable isotope ratios as tracers in marine aquatic food webs, in: Stable Isotopes in Ecology and Environmental Science, edited by: Lajtha, K. and Michener, R. H, 138-157, Blackwell Scientific, 1994.

Middelburg, J. J., Klaver, G., Nieuwenhuize, J., Wielemaker, A., de Haas, W., Vlug, T., and van der Nat, J. F. W. A.: Organic matter mineralization in intertidal sediments along an estuarine gradient, Mar. Ecol.-Prog. Ser., 132, 157-168, 1996.

Middelburg, J. J., Barranguet, C., Boschker, H. T. S., Herman, P. M. J., Moens, T., and Heip, C. H. R.: The fate of intertidal microphytobenthos carbon: an in situ ${ }^{13} \mathrm{C}$-labeling study, Limnol. Oceanogr., 45, 1224-1234, 2000.

Oakes, J. M.: Microalgae and mangroves as carbon sources for estuarine invertebrates: Evidence from stable isotope enrichment experiments, Ph.D. thesis, Griffith Univ., 2007.

Oakes, J. M., Connolly, R. M., and Revill, A. T.: Isotope enrichment in mangrove forests separates microphytobenthos and detritus as carbon sources for animals, Limnol. Oceanogr., 55, 2126-2138, 2010a.

Oakes, J. M., Eyre, B. D., Middelburg, J. J., and Boschker, H. T. S.: Composition, production, and loss of carbohydrates in subtropical shallow subtidal sandy sediments: Rapid processing and long-term retention revealed by ${ }^{13} \mathrm{C}$-labeling, Limnol. Oceanogr., 55, 393-402, 2010b.

Oakes, J. M., Bautista, M. D., Maher, D., Jones, W. B., and Eyre, B. D.: Carbon self-utilization may assist Caulerpa taxifolia invasion, Limnol. Oceanogr., 56, 1824-1831, 2011.

Oakes, J. M., Eyre, B. D., and Middelburg, J. J.: Transformation and fate of microphytobenthos carbon in subtropical shallow subtidal sands: a ${ }^{13}$ C-labeling study, Limnol. Oceanogr., 57, 1846-1856, 2012.

Oakes, J. M., Ross, D. J., and Eyre, B. D.: Processing of particulate organic carbon associated with secondary-treated pulp and paper mill effluent in intertidal sediments: a ${ }^{13} \mathrm{C}$ pulse-chase experiment, Env. Sci. Technol., 47, 13258-13265, 2013.

Purwoko, A. and Wolff, W. J.: Low biomass of macrobenthic fauna at a tropical mudflat: An effect of latitude?, Estuar. Coast. Shelf S., 76, 869-875, 2008.

Rajendran, N., Matsuda, O., Urushigawa, Y., and Simidu, U.: Characterization of microbial community structure in the surface sediment of Osaka Bay, Japan, by phospholipid fatty acid analysis, Appl. Environ. Microbiol., 60, 248-257, 1994.
Rajendran, N., Suwa, Y., and Urushigawa, Y.: Distribution of phopholipid ester-linked fatty acid biomarkers for bacteria in the sediment of Ise Bay, Japan, Mar. Chem., 42, 39-56, 1993.

Schouten, S., Klein Breteler, W. C. M., Blokker, P., Schogt, N., Rijpstra, W. I. C., Grice, K., Baas, M., and Sinnighe Damsté, J. S.: Biosynthetic effects on the stable carbon isotopic compositions of algal lipids: Implications for deciphering the carbon isotopic biomarker record, Geochim. Cosmochim. Acta, 62, 1397-1406, 1998.

Smith, D. J. and Underwood, G. J. C.: The production of extracellular carbohydrates by estuarine benthic diatoms: The effects of growth phase and light and dark treatment, J. Phycol., 36, 321333, 2000.

Stal, L. J.: Microphytobenthos, their extracellular polymeric substances, and the morphogenesis of intertidal sediments, Geomicrobiol. J., 20, 463-478, 2003.

Sundbäck, K., Nilsson, P., Nilsson, C., and Jönsson, B.: Balance between autotrophic and heterotrophic components and processes in microbenthic communities of sandy sediments: A field study, Estuar. Coast. Shelf S., 43, 689-706, 1996.

Underwood, G. J. C. and Paterson, D. M.: The importance of extracellular carbohydrate production by marine epipelic diatoms, Adv. Bot. Res., 40, 184-240, 2003.

Volkman, J. K., Jeffrey, S. W., Nichols, P. D., Rogers, G. I., and Garland, C. D.: Fatty acid and lipid composition of 10 species of microalgae used in mariculture, J. Exp. Mar. Biol. Ecol., 128, 219-240, 1989.

Westrich, J. T. and Berner, R. A.: The role of sedimentary organic matter in bacterial sulphate reduction: the G model tested, Limnol. Oceanogr., 29, 236-249, 1984.

Woulds, C., Cowie, G. L., Levin, L. A., Andersson, J. H., Middelburg, J. J., Vandewiele, S., Lamont, P. A., Larkin, K. E., Gooday, A. J., Schumacher, S., Whitcraft, C., Jeffreys, R. M., and Schwartz, M.: Oxygen as a control on seafloor biological communities and their roles in sedimentary carbon cycling, Limnol. Oceanogr., 52, 1698-1709, 2007. 